ASLI QoL 2017
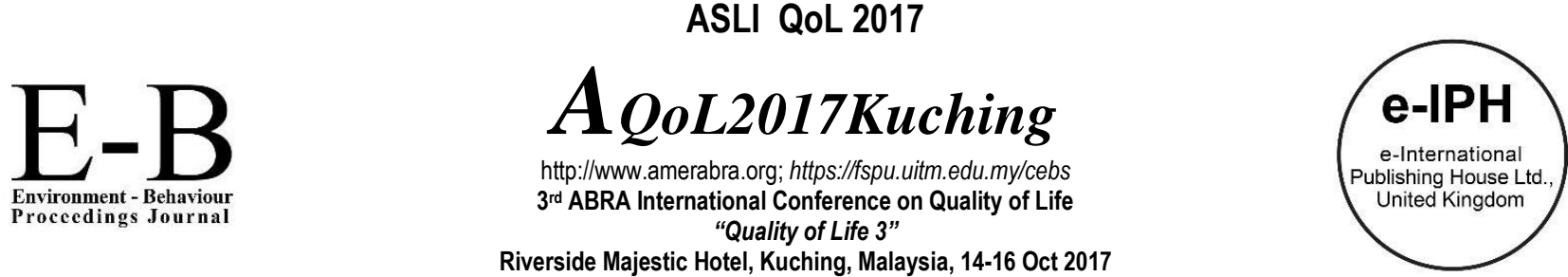

\title{
The Role of Co-housing in Building Sustainable Communities: Case studies from the UK
}

\author{
Jingjing Wang ${ }^{1}$, Karim Hadjri ${ }^{1}$ \\ School of Architecture, \\ The University of Sheffield, UK. \\ jwang130@sheffield.ac.uk
}

\begin{abstract}
This paper explored the role of co-housing model in the UK and discussed the benefits and limitations of co-housing model by exploring co-housing residents' motivation and daily living. Through case studies in the UK, semi-structured interviews were carried out to establish the environmental and social sustainability in co-housing and understand residents thinking and behaviour. This study found that co-housing can benefit various age groups, and promote residents' thinking and behaviour change towards sustainable living. The study also found that the financial limitation and new members recruitment are the top two difficulties in co-housing development. The findings of this research will establish a better understanding of UK co-housing and highlight the potentials and possibilities of co-housing communities.
\end{abstract}

Keywords: sustainable communities; co-housing; environmental sustainability; social sustainability

eISSN: 2398-4287@ 2017. The Authors. Published for AMER ABRA by e-International Publishing House, Ltd., UK. This is an open access article under the CC BYNCND license (http://creativecommons.org/licenses/by-nc-nd/4.0/). Peer-review under responsibility of AMER (Association of Malaysian Environment-Behaviour Researchers), ABRA (Association of Behavioural Researchers on Asians) and cE-Bs (Centre for Environment-Behaviour Studies), Faculty of Architecture, Planning \& Surveying, Universiti Teknologi MARA, Malaysia.

https://doi.org/10.21834/e-bpj.v2i6.946

\subsection{Introduction}

Nowadays a growing number of people pay more attention to the quality of living environment and social life. As a result, a wide range of stakeholders such as architects, engineers, housing officers, community development officers and neighbourhood managers play a part in creating safe, green and friendly living environments to respond this common needs. In 2003, the concept of a 'sustainable community' was proposed by the UK government. A sustainable community is defined as an economically, environmentally, socially positive, mutually beneficial and resilient community. This concept will encourage the government to build communities that will stand the test of time and in which people 'want to live and work, now and in the future' by promoting various housing provision models, such as co-housing. Co-housing is a creative way to achieve the sustainable community concept and to contribute to affordable living. It is a new collaborative housing model in the UK, and it is designed to foster meaningful relationships, social interaction and sustainable living, therefore, leading to the building of a sustainable community. Co-housing has the potential to deliver a supportive housing environment that leads to a low carbon lifestyle and sustainable living. Also, co-housing can be an alternative way to approach housing that could address larger issues of social, economic and environmental sustainability, while providing a better environment for the residents and a wider community.

This paper aims to explore the role of co-housing model in the UK and will discuss the benefits and limitations of co-housing model by exploring co-housing residents' motivation and daily living. Examining whether co-housing model can be used as an evaluation tool to guide thinking and behaviour change and foster sustainable community building. Through case studies in the UK, residents interview will be used in this study to establish the environmental and social sustainability in co-housing and understand residents thinking and behaviour. The findings of this research will establish a better understanding of UK co-housing and highlight the potentials and possibilities of co-housing communities.

eISSN: 2398-4287@ 2017. The Authors. Published for AMER ABRA by e-International Publishing House, Ltd., UK. This is an open access article under the CC BYNCND license (http://creativecommons.org/licenses/by-nc-nd/4.0/). Peer-review under responsibility of AMER (Association of Malaysian Environment-Behaviour Researchers), ABRA (Association of Behavioural Researchers on Asians) and cE-Bs (Centre for Environment-Behaviour Studies), Faculty of Architecture, Planning \& Surveying, Universiti Teknologi MARA, Malaysia. https://doi.org/10.21834/e-bpj.v2i6.946 


\subsection{Literature Review}

\subsection{What is co-housing?}

The word 'co-housing' comes from 'co-operative housing' and is a housing model which offers a possible solution to the housing crisis (Priest, 2015). This housing model is different from Self-build housing and Housing co-operatives. The definition of co-housing by UK Co-housing Network is addressed as a type of intentional community, composed of self-contained homes and supplemented by shared facilities, and the community is planned and managed by residents. It is also an alternative residential arrangement consisting of individual homes facing onto a shared area with a common house for group gatherings (Waxman, 2005). This new collaborative housing concept is designed to foster meaningful relationships, social interaction and energy efficiency concepts. The precious research records that the origin of co-housing began in Denmark in the 1960s (Priest, 2015). The first example of co-housing was designed by Danish architect Jan Gudmand-Hoyer in 1964 (Canadian Co-housing Network, 2016). It was first developed to achieve social interaction and community cohesion in Denmark and the Netherlands (Williams, 2005). Subsequently, co-housing design was found mainly in Sweden, United Kingdom, Canada, Australia and North America (Ruiu, 2014). It is not only home to 50,000 people ( $1 \%$ of the population) in Denmark, but it has become established across Northern Europe and a typical housing model which benefits different age groups. Therefore, the current research aims to extract the core of traditional co-housing theory and explore the role of co-housing in the UK. Also, the current research will fill the knowledge gap by exploring sustainable community building strategies and show the best practice in Sheffield, UK.

Through co-housing, residents are committed to living together as a community and gain the benefit of a supportive social network (Garciano, 2011). Co-housing residents are encouraged to participate in the physical layout design, space planning, common facilities and meal sharing community activities and management of their neighbourhood (Garciano, 2011). In particular, Sargisson (2010) pointed out, 'Consensus' is the heart of the system of management in co-housing communities even if it requires time, patience, funds and a strong willingness to solve the internal and external issues.

A co-housing community is designed for separate living within a common area and shared duties (Waxman, 2005). Also the design of residential environment is related to the quality of life (Aulia, et al. 2017). It is a group of between 8 and 40 households emphasizing a multi-generational mix of singles, couples, families with children, and older people. They come together and share facilities and belongings as an extended family. The community may reduce the living costs by shared resources, advanced environmental technologies, education and other social services, such as shared gardens, cars, child and elderly care, caregiver support, tutoring and training (Priest, 2015 \& Garciano, 2011). In fact, as stated by the UK Co-housing Network (2016), co-housing communities have a common house, with shared facilities such as cooking and dining spaces, meeting and playing areas, laundries and guest rooms. Shared outside space for children's play, parties and gardening can feature in a co-housing project.

\subsection{Current situation of Co-housing communities in the UK}

Along with the development of the housing market over the past two decades, 19 Co-housing communities were built all over the country, 38 listed co-housing groups are in development and five listed groups are forming their membership (UK Co-housing Network, 2017). There are several types of co-housing in the UK, such as senior, intergenerational, vegan and vegetarian, eco and self-build co-housing. Different visions and focuses will decide the feature of the community and be attractive to various groups. Nowadays, a growing number of design companies, decision makers and local authorities are devoted to pushing forward the development of co-housing communities, such as Sheffield city council and Sheffield Co-housing Network in Yorkshire. However, compared with the development level of UK housing market, most of the co-housing projects are self-funded by the residents as there is no public funding for co-housing (UK Co-housing Network, 2017). Due to the community size, shared ownership, land price, location and community financial model are different, co-housing schemes are still on a small scale and need to be more cost-effective.

\subsection{Why Co-housing?}

With existing pressure of addressing environmental and social sustainability, more people are looking for alternative ways to home themselves and to be part of the community. Benefits associated with co-housing, specifically, shared household tasks, private living space combined with easy access to socialising; pooled financial resources; the safe environment in which children can grow; and a type of extended family made up of people of diverse ages, interests and backgrounds (Waxman, 2005 p57). Additionally, co-housing communities provide opportunities for individuals to participate in experiences, community tasks, activities outside their traditions and customs (Waxman, 2005). Such as pet sit, share skills in cooking, growing or just socialising in the common house. The feature of community design and the nature of sharing may potentially reduce social isolation, especially for the older people (UK Co-housing Network, 2017); and create a sense of belonging which lead to the identity of the community (Yousefi et al. 2017). Apart from the social aspect, co-housing communities offer a platform for residents to interact with nature and the land (Sanguinetti, 2014). More sustainable technologies can be introduced to the community, such as biomass boilers, composting and solar panels. The co-housing model is effective in inspiring people how to make their life greener and healthier. For example, the vegetable and fruit planting on site could support the community food supply, nourish the land and reduce the footprint to the environment. 


\subsection{Sustainable living in co-housing community}

"The community represents a totality of life not only in its inner extent but also because for many it is identical with the totality of life itself. In this sense the community becomes 'home' in the strictest sense, not only because it embraces the basic and average form of all social activities, but because in addition it contains an element of nature as certainly as each community is always a part of its social and cultural context." (König, 1968, p.5)

In a co-housing community, the common meal is a typical 'symbol' in this housing model; it is also an important aspect of community life both for social and practical reasons (McCamant \& Durrent, 2011). Each home is self-sufficient with a kitchen, but diners are available at the common house for those who wish to participate. In some communities participants will join the cooking team once or twice a week then sit and enjoy meals cooked by fellow residents (Canadian Co-housing Network, 2016; UK co-housing Network, 2017). Apart from the common meal, other activities could be found in the community, such as regular meetings, weekly community working, outdoor maintenance, coffee or afternoon tea meetings. In sum, co-housing provides personal privacy combined with the benefits of living in a community where people know and interact with their neighbours. The participatory process is fundamental to the establishment of a co-housing development, creates strong, supportive and 'family' bonds between residents that are reinforced by the long-term ownership and maintenance of the communal areas. In addition, neighbourhood design helps reinforce this sense of community (Fromm, 2000 \& Garciano, 2011). Social benefit brought by stronger community relationship, potentially saving money and lowering their environmental impacts, while also changing their lifestyle and outlook (Morrison, 2013). Allowing individuals to think beyond themselves, at their impact on a wider neighbourhood and the environment.

At the same time, co-housing model could encourage residents to make more contributions to their surroundings (Morrison, 2013). More environmentally friendly behaviour can be seen in the community. The communal facilities and layout help encourage sharing of resources; from car-pooling and washing machines, buying food in bulk for communal and individual's meals, to the sharing of tools for garden and building maintenance. Besides, fruits and vegetable planting, gardening, composting, rainwater collection, making 'green roof' and waste sorting, these are inspiring co-housing residents to live in a sustainable and creative way, not only create a beautiful living environment but make the best of the land while reducing their footprint. To this end, co-housing has a great potential to contribute to the sustainable development of its area, meaning making it more liveable while maintaining affordable dwellings.

\subsection{Methodology}

This study aims to examine the advantages and limitations of co-housing and the extent to which it can lead to building sustainable communities, by exploring residents' preferences, daily activities and the multigenerational living in co-housing case studies in the UK. By examining people's motivation for co-housing building, this research will develop methods to encourage a greater commitment to co-housing and sustainable living environments.

In order to understand the co-housing development, interviews with stakeholders through three co-housing projects have been used. This qualitative approaches offered more opportunities to explore the differences and similarities of people's lives and to find out the actions and thoughts of people (Strauss \& Corbin, 1998). The interviewees are the members from these three co-housing groups, The Open House project, Five Rivers co-housing and On The Brink Co-housing. Also, the research can compare the various developing stages and features between different co-housing groups in Sheffield and explore how co-housing can be used as an evaluation tool for environmentally sustainability to guide behavioural change and foster closer, inclusive, sustainable communities. The methodology has been explained through the following flowchart (Fig. 1).

\subsection{Case selection}

In this study, three co-housing communities are chosen for the data analysis. They are both located in Sheffield, and they are members of a new co-housing union, The Sheffield Co-housing Network. There are five co-housing groups in Sheffield, which are in different developing stages. Four groups selected their sites while the other group is collecting ideas for location. Two communities have been designed and built; other groups are still in planning or under the construction. Sheffield co-housing groups have rich resources for co-housing researchers to understand the co-housing development process. Co-housing models in Sheffield involved self-build and historical property retrofit experience and environmentally sustainable technologies. The communities have been designed to involve both young and older residents. These projects are good examples to understand how co-housing model works with different age groups and how community space has been planned and used, why people come and build their community in Sheffield and what their motivations are in a local context. Considering the data accessibility and the case location, The Open-House Project, On the Brink co-housing and the Five Rivers co-housing were selected for further data analysis. The location of these cases is shown below (Fig. 2), Five Rivers co-housing group is still collecting ideas for location. 


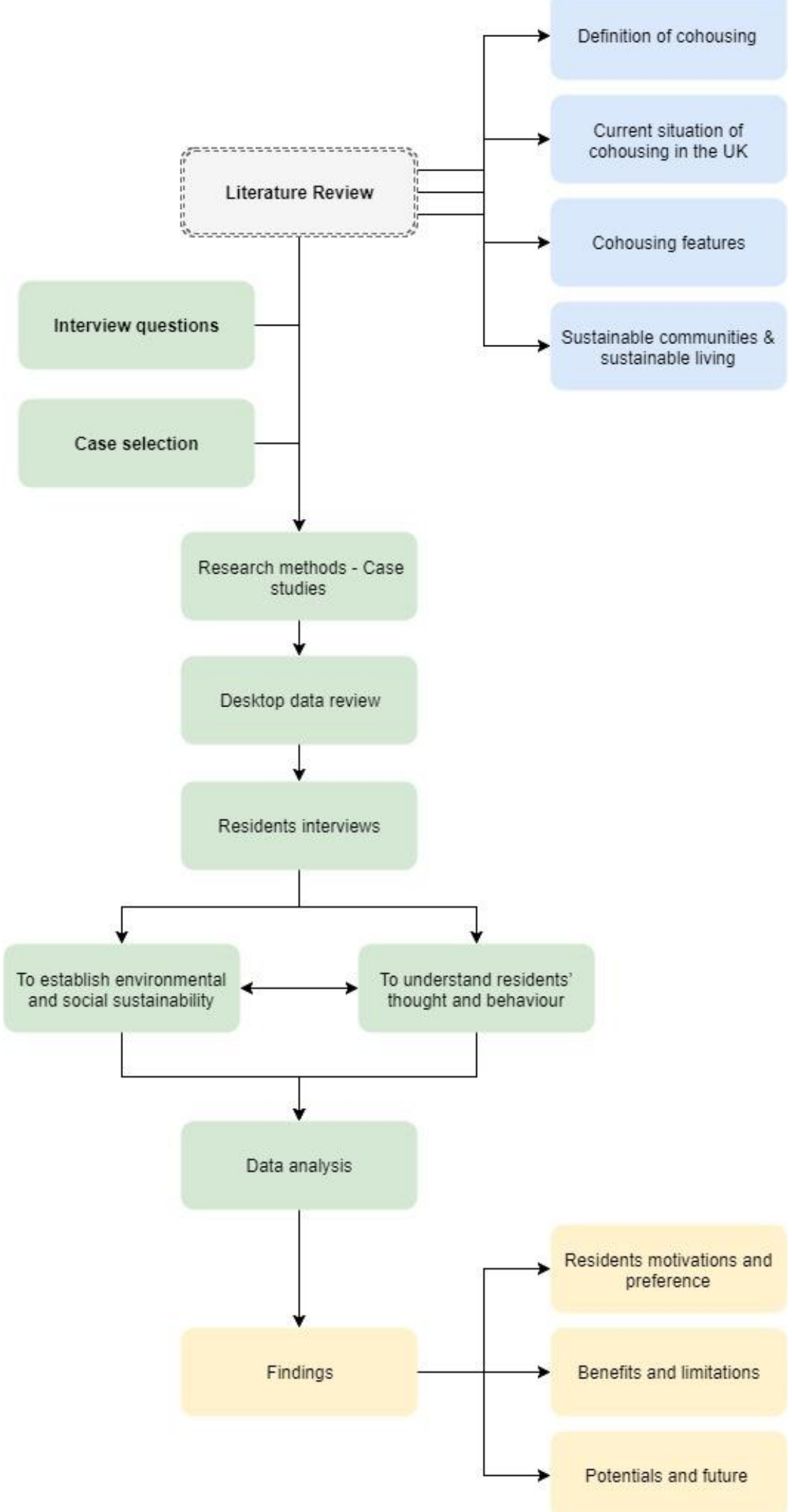

Fig. 1: Methodology Flowchart (Source: Author) 


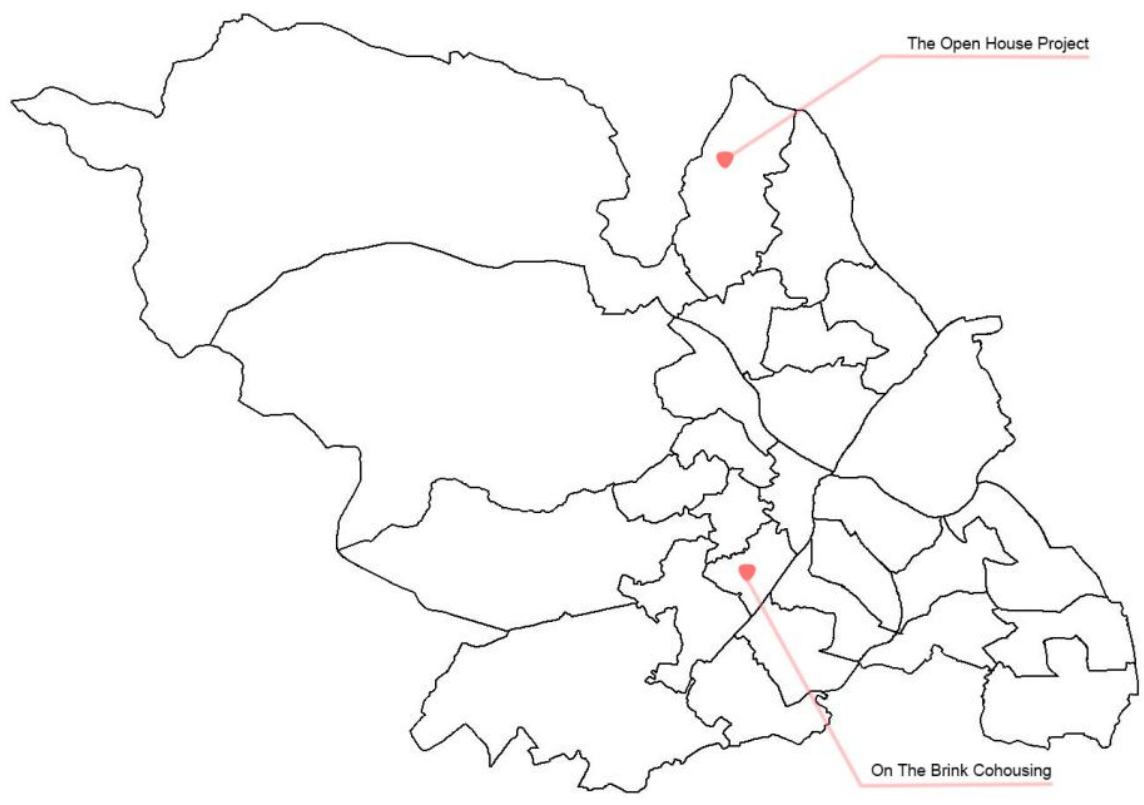

Fig. 2: Case study sites in Sheffield (Source: Author)

\subsection{Desktop review}

The desktop research is fundamental and provides a big image for the selected case studies. It covers the existing data in projects vision, residents type, construction type, case location, development stages, the project starting time and how many members the project currently have.

Table 1. Desktop review of co-housing projects

\begin{tabular}{|c|c|c|c|}
\hline & The Open House Project & On The Brink co-housing & Five Rivers co-housing \\
\hline $\begin{array}{l}\text { Brief of the project } \\
\text { vision }\end{array}$ & $\begin{array}{l}\text { - To provide a range of homes, for } \\
\text { families or individuals who at any } \\
\text { stage in their life } \\
\text { - To facilitate mutual support through } \\
\text { shared meal and activities, } \\
\text { consensus decision making, and } \\
\text { thoughtful design. (regular meeting, } \\
\text { common meals, common spaces, } \\
\text { facilities and shared resources) } \\
\text { - Low environmental impact (energy } \\
\text { use, waste disposal and use of } \\
\text { vehicles) } \\
\text { - Develop links with the wider } \\
\text { community }\end{array}$ & $\begin{array}{l}\text { - Private living space and } \\
\text { communal space for sharing } \\
\text { resources, work and mutual care } \\
\text { - Socially sustainable community } \\
\text { based on companionship, } \\
\text { ecological living and mutual } \\
\text { respect for each other } \\
\text { - As ecologically sustainable way } \\
\text { as possible } \\
\text { - Engage with wider community } \\
\text { - Grow plants and managing the } \\
\text { natural environment } \\
\text { - Have fun, enjoy life and learning } \\
\text { from each other }\end{array}$ & $\begin{array}{l}\text { - The community based-on } \\
\text { private dwellings with a high } \\
\text { degree of co-operation and } \\
\text { shared space, values and } \\
\text { resources. } \\
\text { - Achieve high environment } \\
\text { standards. } \\
\text { - Reduce residents' carbon } \\
\text { footprints and living cost by } \\
\text { sharing } \\
\text { - Regular meeting and } \\
\text { consensus decision making } \\
\text { - Offer affordable homes to } \\
\text { range of households }\end{array}$ \\
\hline Residents type & $\begin{array}{l}\text { Mixed-age group, the } \\
\text { multigenerational living }\end{array}$ & $\begin{array}{l}\text { Mixed-age group, } \\
\text { the multigenerational living }\end{array}$ & $\begin{array}{l}\text { Mixed-age group, } \\
\text { the multigenerational living }\end{array}$ \\
\hline Construction type & $\begin{array}{l}\text { Convert the farm buildings (historical } \\
\text { site) }\end{array}$ & Refurbishing the historical building & New-build \\
\hline Location & Barnes Hall Farm, Burncross, & Brincliffe House, Nether Edge & 1 \\
\hline Development Stages & $\begin{array}{l}\text { - Set up a company; } \\
\text { - Moved into the first house in Jan } \\
\text { 2016; } \\
\text { - Building the second house. }\end{array}$ & $\begin{array}{l}\text { - Set up a community interest } \\
\text { company; } \\
\text { - Site selected; } \\
\text { - Waiting for investment } \\
\end{array}$ & $\begin{array}{l}\text { - Set up a company; } \\
\text { - Developing collective ideas for } \\
\text { location, architecture and site } \\
\text { layout. }\end{array}$ \\
\hline Starting time & 2011 & 2014 & 2012 \\
\hline Group members & 10 adults and 8 children & 9 & 5 paid up members \\
\hline
\end{tabular}

(Source: The Open House Project: https://openhouseproject.wordpress.com/, On The Brink co-housing: https://onthebrink.community/, Five Rivers co-housing: https://sheffieldcohonetwork.wordpress.com/current-groups/) 


\section{Case Study 1: The Open-House Project, Sheffield, Yorkshire}

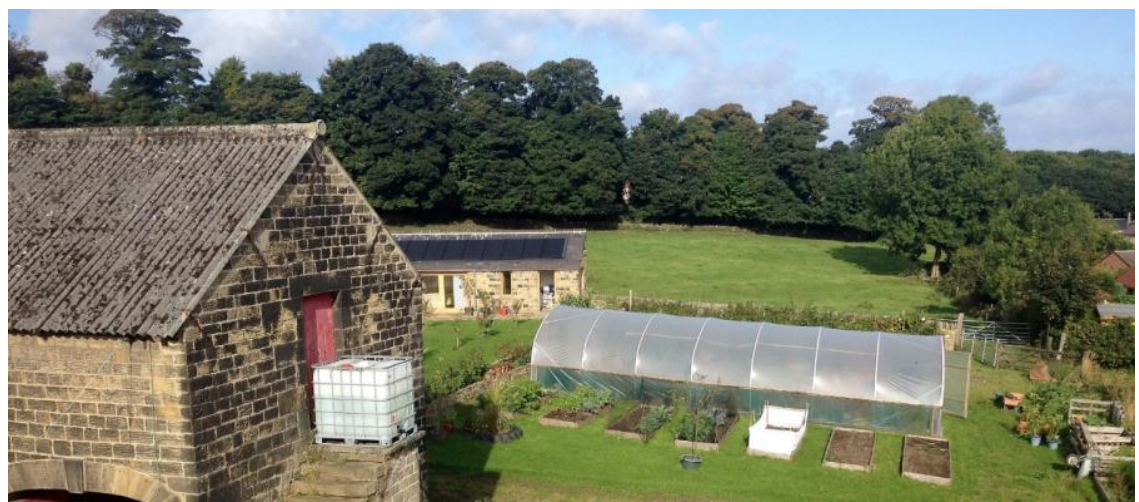

Fig. 3: View of the existing buildings, Case study 1

(Source: https://openhouseproject.wordpress.com/co-housing-design/)

The Open House Project is located at Barnes Hall Farm, Burncross, Sheffield. The group has purchased a farm, and now received planning permission to convert the farm buildings into seven dwellings, communal facilities and shared outdoor spaces. This cohousing group works within a historical site, 5 of the buildings are set around a courtyard (Figure 4), which lends itself to a co-housing set-up. This project employed PV panel, Biomass boiler and breathing wall construction techniques on site. (Open House Project, 2016).

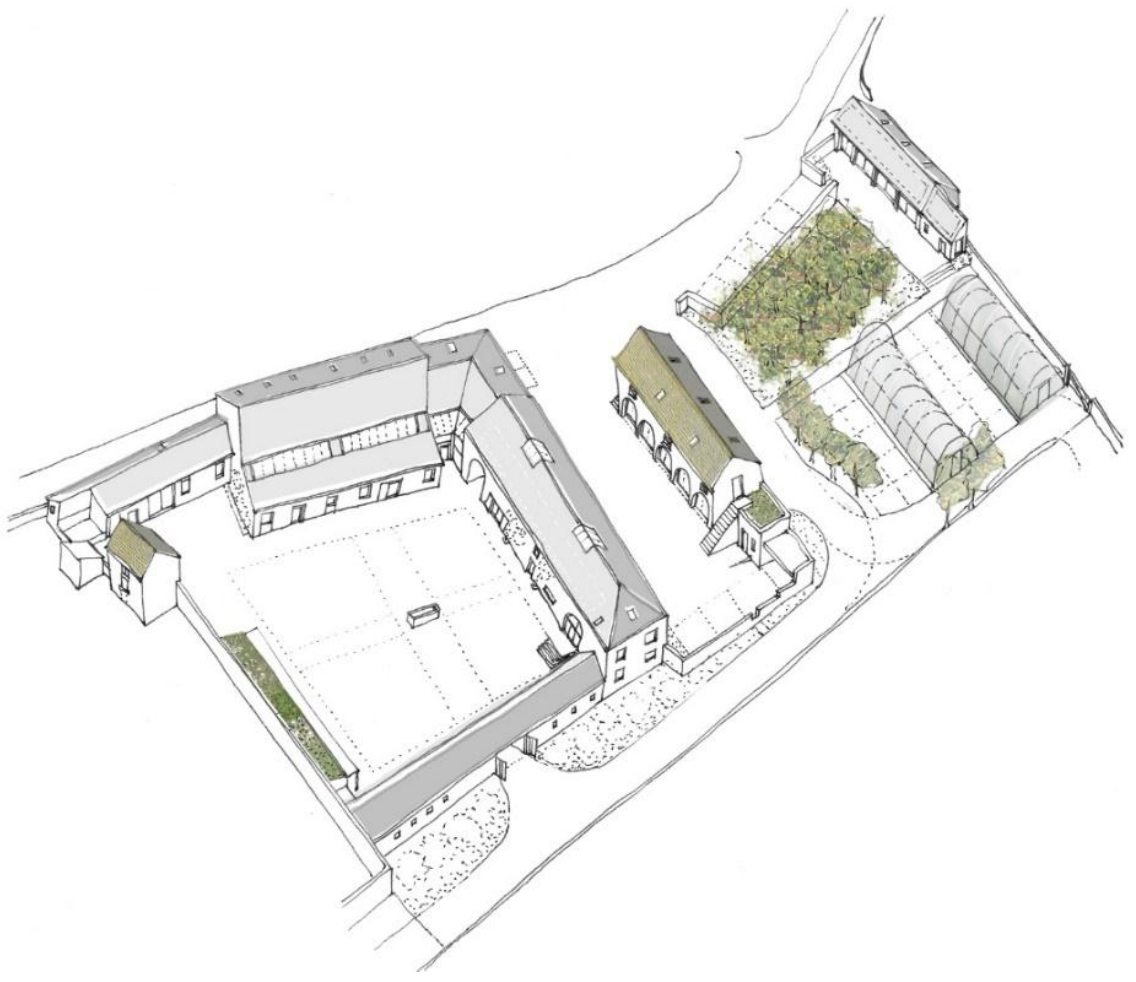

Fig. 4: Site plan, Case study 1

(Source: https://openhouseproject.wordpress.com/co-housing-design/)

\section{Case Study 2: On The Brink Co-housing, Nether Edge, Sheffield}

On the brink are a group of nine individuals who come together after a long journey looking for a site. The group decided to buy Brincliff House in Nether Edge, Sheffield (Fig. 5). They are also working with the historical site which had been previously used by the NHS. Within the group there is a range of expertise and they meet regularly to discuss the project. They are looking for investors who will be willing to lend the capital for the short and long term. (On The Brink, n.d.) 


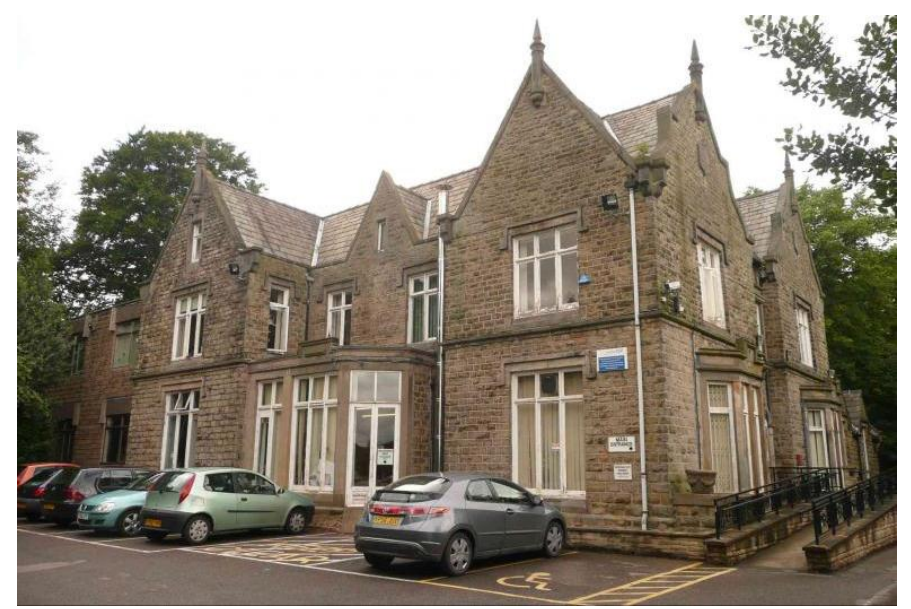

Fig. 5: View from outside of Brincliffe House, Case study 2

(Source: http://our.property.nhs.uk/index.php?id=151\&property=4995)

\section{Case study 3: Five Rivers co-housing}

Five Rivers are a group of people who come together to create and manage a co-housing project in Sheffield. The group are aiming to develop a multigenerational, mixed tenure and eco-friendly new-build community. Group members are meeting regularly, investigating sites and discussing the project. This co-housing group are developing collective ideas for the location and community design.

\subsection{Co-housing resident interviews}

Semi-structured interviews were conducted with the residents, founder members and architects. The open-ended questions aim to expand the participants' points and they were used to elaborate the opinions and views of the participants involved in the project. Seven people were recruited for the interview process; they are the co-housing members from the selected cases. Each interview took 40-60 minutes on site or by telephone. The conversations were recorded with the participants' permission for further analysis. Also, the interview activity follows the University's ethics guide by using Participants Information Sheet (PIS) and Consent Form (CF). The interview questions were developed based on findings from the literature review and desktop data. Nine interview questions were used, which were targeting a) residents and founder members' motivation and preferences, b) community design and sustainable living, c) current limitations and disadvantages and, d) affordability. The questions are listed below:

Motivation and Preferences:

1. What is your 'motivation' to create/join a community?

2. Why did you choose to move into this co-housing community? What are the most important factors for your consideration or choice of this community?

Community design and sustainable living:

3 Do you think that co-housing is an option for older people and would multigenerational living be attractive in this context?

4. Would you prefer to live in an intergenerational co-housing or senior co-housing? Why?

5. How can co-housing contribute to sustainable living?

6. How the co-housing community living affects your thinking and behaviour?

7. Could co-housing model fit into Part M design (Lifetime Home) standard for the future Use?

Limitations and disadvantages:

8. What is the current limitation and disadvantages of co-housing model in the UK?

Affordability:

9. Affordability is normally a driver for co-housing. How can co-housing be an affordable option to different social groups?

\subsection{Research methods limitations}

The research methods in this study are restricted by the number and the age range of participants. The sample size in this study is still small. 7 participants are involved in this study; 5 of them are older people; 2 of them are middle-aged.it is not include children and young families. Therefore, the findings of research is focused on the older people's opinion and preference. In addition, due to the development progress of the selected cases are different, only one site visit has been done. The physical design information of the co- 
housing communities are limited. The research is looking for more information to analyse how co-housing living environment affects residents' daily activities and behaviour.

\subsection{Findings}

This research is based on 7 interviews conducted during the summer of 2017 in Sheffield. The interview data were analysed according to the interview questions. Recordings were transcribed to extract the main concepts and key themes. The similarities and differences of answers for each question were compared between participants. The common ideas and concepts became the major trends to help establish the role of co-housing in wider context. The interview findings were grouped and analysed into four sets, a) Motivation and Preferences, b) community design and sustainable living, c) limitation and disadvantages, and d) affordability. The number in the bracket shows how many times the concept has been mentioned by the participants (Table 2). The ideas have been mentioned four or more than four times were extracted as main findings.

Table 2. Interview results

\begin{tabular}{|c|c|}
\hline Interview question groups & Themes and ideas from participants interviews \\
\hline Motivation and Preferences & $\begin{array}{l}\text { Have people around to support you and you also can support others (6) } \\
\text { Sense of community and being part of the community (5) } \\
\text { Personal previous experience as the motivation (4) } \\
\text { Multigenerational living is attractive (4) } \\
\text { Closer with the people who can share my values (3) } \\
\text { Co-housing community setting: private dwelling plus communal area for sharing; meet social } \\
\text { and private needs (3) } \\
\text { Sense of home (2) } \\
\text { Reduce isolation for older people (2) } \\
\text { Happy with the location or the site (2) } \\
\text { Living closer together with family members (2) } \\
\text { Nice, kind and gentle group member (1) } \\
\text { Family members' wish to create or to join a community group (1) } \\
\text { Good environment for children to grow up (1) } \\
\text { Meet the social demands (1) } \\
\text { Downsizing and financial difficulties (1) }\end{array}$ \\
\hline $\begin{array}{l}\text { Community design and sustainable } \\
\text { living }\end{array}$ & $\begin{array}{l}\text { Helpful for different age group, promote multigenerational living (7) } \\
\text { Helpful for older people to maintain their independence (6) } \\
\text { Could be an option for older people (5) } \\
\text { Promote thinking and behaviour change (5) } \\
\text { Co-housing could make contribution to sustainable living (5) } \\
\text { Contribution to social sustainability (4) } \\
\text { Co-housing is able to introduce environmental technologies and building technologies to the } \\
\text { site. e.g. ground heating, solar panels(3) } \\
\text { Co-housing model may fit into Part M (Lifetime home) design standard, but build that into the } \\
\text { ownership is challenging ( } 3 \text { ) } \\
\text { Establish something for the long term for the environment (2) } \\
\text { Give space to grow things (2) } \\
\text { Be a part of an extended family (2) } \\
\text { Have more opportunity to learn from each other (2) } \\
\text { Look after the listed historical buildings on site and look after the land (2) } \\
\text { It is possible to save energy (1) } \\
\text { Co-housing idea is not completely new; it is in some way going back to a kind of living in the } \\
\text { past and going back to the closer life it should be (1) } \\
\text { Trust people (1) } \\
\text { Reduce food waste (1) } \\
\text { Co-housing members will experience happiness by helping and supporting others (1) } \\
\text { No organisation to support co-housing group to gather members or gather information of } \\
\text { people's interests (1) }\end{array}$ \\
\hline Limitations and disadvantages & $\begin{array}{l}\text { Financial limitations to develop or join a co-housing (4) } \\
\text { Having difficulties to recruit new or young members (4) } \\
\text { Due to the personality and the nature of the community, it may have social limitations (3) } \\
\text { Difficult developing process, requires lot of work, meetings and energy (3) } \\
\text { Lack of social housing in the UK (3) } \\
\text { Decision making sometimes is difficult (3) } \\
\text { Balance between privacy and publicity (2) } \\
\text { Self-sufficient in food is a big challenge (2) } \\
\text { Politeness; To be able to speak what you need, speak honestly, calmly without being } \\
\text { aggressive and upset others is hard (2) } \\
\text { Community living can be challenging (1) } \\
\text { Pet can be a challenging issue (1) }\end{array}$ \\
\hline
\end{tabular}




\begin{tabular}{l}
\hline Food choice can be a challenging issue. e.g. vegan and vegetarian (1) \\
Get a site (1) \\
If move out, concerned about selling the property (1) \\
The type of living may maintain cultural and religious barriers depending on member's \\
background (1) \\
Technical limitations of the use of environmental technologies (1) \\
\hline $\begin{array}{l}\text { It is difficult for people who do not have capital, e.g. young couple (7) } \\
\text { Mutual home ownership or co-ownership society could be helpful to involve different social } \\
\text { groups (4) } \\
\text { Rental element may be helpful or may cause tensions (3) } \\
\text { Need more financial supports and social housing supports from the government and local } \\
\text { council (3) } \\
\text { How could get the finance quicker is an issue (1) } \\
\text { Where to borrow the money to keep the project up and running (1) }\end{array}$ \\
\hline
\end{tabular}

According to the feedback from the residents' interview, the main findings are showed below (Fig. 6); the mutual supports between community members, sense of community and multigenerational living became the top three important factors to motivate people to create or join a co-housing community. All of the participants of this study prefer to live in a mixed-age group. The significant advantages have been found in this research refer to the benefits to various age groups, especially older people to maintain their independence to age-in-place. Also the community physical design and sustainable living are possible to promote residents' thinking and behaviour change. For the current challenges and disadvantages for co-housing living, the financial limitation to develop or join a co-housing community and new members recruitment are the top two difficulties which the groups are facing. In addition, the heavy community meetings and works and lack of social housing support are also affecting co-housing groups. Regarding the affordability aspects of co-housing community, people who do not have the capital are finding it difficult to join the community. Mutual home ownership or co-ownership and rental elements may able to help this situation, but it depends on the setting and vision of the cohousing group.
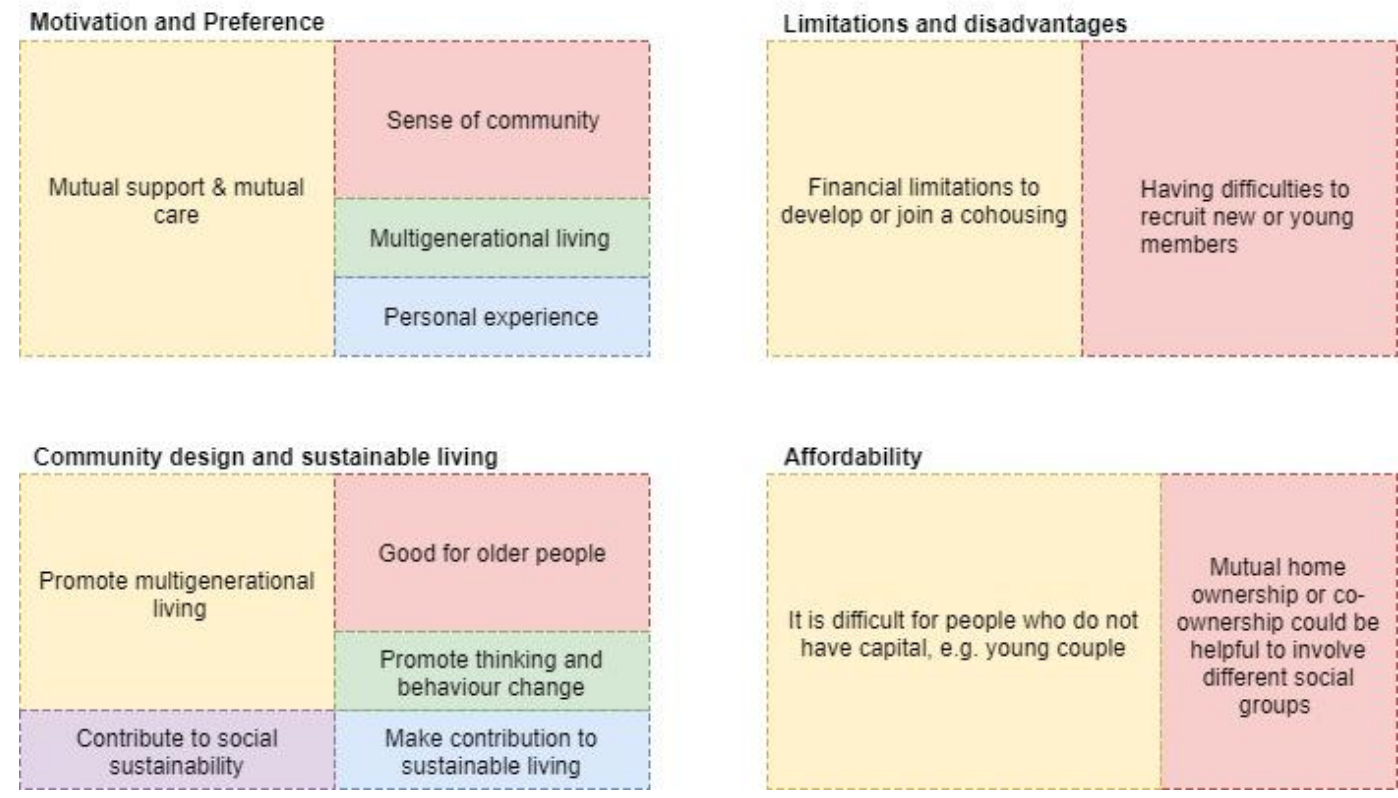

Fig. 6: Main findings

(Source: Authors)

\subsection{Discussion}

This paper aims to examine the advantages and drawbacks of co-housing communities by exploring residents' motivation, preferences and their opinions on shared community living through case studies. Comparing the project visions in the desktop data review, mutual support/care, low impact living and link with wider community are the common interests and wishes to residents within the selected projects. All levels of sustainability (social, environmental and economic) are considered and established within the cohousing development process. Due to the differences of location and community design, groups are facing various issues, such as pet, food choice and land purchase. However, the projects are trying to involve different age groups and sharing common values to make contributions to the sustainable community building. Furthermore, the limitations and drawbacks still remain. How to make this housing schemes available and affordable to the various social groups is a long term issue. More and more groups are looking for 
mixed-age co-housing groups, but the young people and young families are in a difficult situation to join a co-housing due to the financial limitations. Moreover, it is necessary to obtain some supports from the government and local council. There is no structural and complete guide in the UK for the co-housing community development process. Also the lack of support from social organisation in promoting community leadership and communication is obvious. It is the aim of this research to support more co-housing groups to create their communities in the future.

In addition, this research inspires more people thinking; such as unbalanced UK housing market, lack of affordable housing, liveable community building, more comprehensive social care and the issues of social isolation. The co-housing model offers a living option for different age groups and provides them a mutual-support community. Also, the study of co-housing model could provide the useful solution of the mentioned issues. However, UK co-housing communities are still in a small scale. This living model is still need more theoretical, social and financial supports. It also requires more sociological research to explore people's current and previous living styles and relationships between generations and cultures.

\subsection{Future Challenges of co-housing}

According to Garciano (2011), the unique characteristics of co-housing neighbourhood, such as the intention to establish small houses and communities, the participatory planning process with residents and community-focused operations, may not always fit well in the current world of a co-housing scheme and its funders. Its development may be influenced by several factors, such as personal experience, educational level, government policy, culture and underwriting criteria of public and private funders.

Co-housing can be an innovative community model to enhance residents' interaction with each other and with nature (Sangunietti, 2014). However, how to you make co-housing models benefit a wider society and the environment? Some co-housing settlements in the UK showed a better performance, such as LILAC project, Leeds. While, as Marckmann, et al. (2012) stated, the outcomes and developments are not unambiguously in favour of co-housing, especially not compared with an average apartment building.

Co-housing communities use more sustainable technologies built into houses, but at the same time, the risk that technology would take up a disproportionate amount of maintenance time and energy (Marckmann et al. 2012). In other words, it is vital to keep the balance between having environmentally friendly technologies and what would be acceptable to residents. Usually, most environmental protection measures are linked with residents' behaviour. It will make this study data collection harder and also remains uncertain how the co-housing scheme would work in a broader population. Finally, co-housing communities could also encourage their residents to interact with nature and sustainable food production (Sangunietti, 2014), for example, supporting local food systems. However, self-sufficient in food is still a big challenge, and this could be restricted to the land, surroundings and climatic factors (Marckmann et al. 2012).

Additionally, it is necessary to support co-housing groups from the government's perspective by exploring more possible public funding to make these housing schemes available and affordable to different social groups, such as young couples and young families. Also, due to the long time development process, where the group is seeking finance are future questions to consider. This will help to reduce the development time and get more people involve the project if they are interested.

\subsection{Conclusion and Future Research}

This research examined the co-housing model in Sheffield and provided a better understanding of the benefits, challenges and trends of co-housing communities. The comparison of the case studies has highlighted the potentials of co-housing, which can also be an option for older population to age-in-place. Because the older people play a very important role of co-housing community building, the future research will pay more attention on how co-housing living affects older people's thinking and behaviour; and how to improve the physical design to meet their environmental and social needs. This research will become a valuable reference for co-housing development in the UK and merit the attention of various age groups, social and health care providers, architects and designers, and policy-makers.

Also, the research is able to show the limitations of the co-housing model and to provide sustainability and affordability guidance of co-housing designs. At the same time, the co-housing study becomes a milestone of the evolution of housing provision, leading to the change of people's thinking and behaviour. The findings of this study could be a useful tool to achieve sustainable community building, and could benefit a wide range of stakeholders. It could also potentially be applied to different settings and environments in the UK and beyond, accelerating the implementation of environmentally friendly homes and sustainable communities.

\section{Acknowledgements}

I would like to acknowledge the support offered by The Open House Project members, On The Brink co-housing group and Five Rivers co-housing group, and thank the support given by my supervisor, Karim Hadjri, and my colleagues. 


\section{References}

Aulia, D., Marpaung, B., \& Zahrah, W. (2017). Place Shaping in Residential Area as a Process of Increasing Livable Neighbourhood. 5th AMER International Conference on Quality of Life, Bangkok, Thailand, 2(5), 307-313. DOI: http://dx.doi.org/10.21834/e-bpj.v2i5.715

Canadian Co-housing Network. (2016). What is co-housing? Retrieved from http://co-housing.ca/what-is-co-housing/

Fromm, D. (2000). American Co-housing: The First Five Years. Journal of Architectural and Planning Research, 17, 94-109.

Garciano, J. L. (2011). Affordable Co-housing: Challenges and Opportunities for Supportive Relational Networks in Mixed-Income Housing. Journal of Affordable Housing \& Community Development Law, 20(2), 169-192.

König, R. (1968). The community. London: Routledge and Kegan Paul Ltd.

Marckmann, B., Gram-Hanssen, K., \& Christensen, T. (2012). Sustainable living and co-housing: evidence from a case study of eco-villages. Built Environment, 38(3), 413

McCamant, K., \& Durrent, C. (2011). Creating Co-housing: Building Sustainable Communities. Gabriola Island, BC: New Society Publishers.

Morrison, J. (2013). A future for affordable housing: Can co-housing ne a viable model for delivering affordable housing in the UK? (Master thesis), The University of Sheffield, Sheffield, UK.

On The Brink. n.d. Retrieved from https://onthebrink.community/who-are-we/

Open House Project, (2016). Retrieved from https://openhouseproject.wordpress.com/

Priest, I. (2015). Different kind of living. RIBA Journal, 122(10), 54.

Ruiu, M. L. (2014). Differences between Co-housing and Gated Communities: A Literature Review. Sociological Inquiry, 84(2), 316-335.

Sanguinetti, A. (2014). Transformational practices in co-housing: Enhancing residents' connection to community and nature. Journal of Environmental Psychology, 40, 86-96.

Sargisson, L. (2010). Co-housing: a utopian property alternative?. Retrieved from https://www.nottingham.ac.uk/cssgj/documents/working-papers/wp014.pdf

Strauss, A., \& Corbin, J. (1998). Basics of Qualitative Research (2nd ed). London: SAGE Publications Inc.

UK Co-housing Network. (2017). Co-housing in the UK. Retrieved from http://co-housing.org.uk/co-housing-uk

Waxman, G. (2005). Who lives in co-housing: Personality and preferences of co-housing residents. ProQuest Information and Learning Company.

Williams, J. (2005). Designing Neighbourhoods for Social Interaction: The Case of Co-housing. Journal of Urban Design, 10(2), 195-227.

Yousefi, Z., Hosseini. S., Yazdanfar, S., \& Norouzian-Maleki, S. (2017). Promoting the Residents' Sense of Belonging in Housing Design. Asian Journal of Behavioural Studies, 2(5), 33-43. DOI: https://doi.org/10.21834/ajbes.v2i5.47 